International Journal of Instruction e-ISSN: 1308-1470 • www.e-iji.net
July $2018 \bullet$ Vol.11, No.3

p-ISSN: 1694-609X

pp. $77-90$

Received: 23/10/2017

Revision: 28/02/2018

Accepted: 06/03/2018

\title{
Think-Talk-Write Model for Improving Students' Abilities in Mathematical Representation
}

Supandi Supandi

Universitas PGRI Semarang, Indonesia, supandi@upgris.ac.id

\section{S. B. Waluya}

Prof., Semarang State University, Indonesia, s.b.waluya@mail.unnes.ac.id

Rochmad Rochmad

Assoc. Prof., Semarang State University, Indonesia,rochmad@mail.unnes.ac.id

Hardi Suyitno

Prof., Semarang State University, Indonesia, hardi.suyitno@mail.unnes.ac.id

\section{Kamelia Dewi}

Universitas PGRI Semarang, Indonesia, kameliadewi94@gmail.com

Mathematical representation is an important skill in mathematics learning that enables students to interpret and solve problems with ease. However, building confidence in such a skill can be difficult for some students, especially for those who lack self-motivation skills. Therefore, this study examines the effects of the think-talk-write strategy and the expository strategy on students' abilities in mathematical representation in order to understand the relationship between mathematical representation and self-efficacy. In this study, a Quasi-Experiment design comprising the experiment group and the control group was applied. Learning process by Think-talk-write (TTW) strategy was implemented in the experiment group only. On the other hand, the learning process in the control group was accomplished without the TTW strategy. The sample in this study comprised students of the eighth grade studying geometry and spatial relations at a public junior high school. For the purpose of this study, two groups were created: 1) an experimental group, in which the think-talk-write strategy was employed, and 2) a control group, in which the expository approach was applied. In addition, mathematical representation ability and self-efficacy scale tests were used as the instruments of this quasi-experimental study.

Keywords: mathematical representation, self-efficacy, learning strategy, expository strategy, think-talk-write strategy 


\section{INTRODUCTION}

Mathematical representation is a key concept in mathematics learning that enables students to interpret and solve problems with ease. In this regard, the National Council of Teachers of Mathematics (2000) indicated that students need to master three aspects in order to effectively solve mathematical problems: select, apply, and translate. In addition, due to the demands of current mathematics curriculums, students are presented with open problem-solving tasks (Chick \& Watson, 2001) in which mathematical representation can be applied to externalize and present their findings (Kalathil \& Sherin, 2000). However, building confidence in such a skill can be difficult for some students, especially for those that lack self-motivation.

Previous research on mathematical representation has only focused on students' cognition abilities (Minarni at al., 2016). However, numerous studies on students' selfefficacy in mathematics have been conducted, including one that examined their performance experiences (Bandura, 1997). Other studies have also investigated the relationship between self-efficacy and students' achievements (Rutherford et al., 2017; Skaalvik at al., 2015; Xu \& Jang, 2017). Previous studies have also shown that students with high self-efficacy tend to have higher academic performance (Siriparp, 2015), and that greater confidence in learning not only increases performance but also improves problem-solving efficiency (Hoffman \& Spatariu, 2008). However, research on students' self-efficacy in mathematical representation has been limited. As a consequence, it is necessary to study the relationship between self-efficacy with mathematical representation through certain learning strategy. Therefore, this study examines the effects of the think-talk-write strategy and the expository strategy on students' abilities in mathematical representation in order to understand the relationship between mathematical representation and self-efficacy. The think-talk-write strategy is a cooperative learning model comprises stage of think, talk, and write. This strategy constructs thought, reflection, and organizes ideas. Subsequently, students should write based on their ideas. The think-talk-write includes 3 phases consist of (1) Students learn the material (thinking), (2) Students discuss the results of learning material (talk), (3) Students write the ideas obtained from talk phase (write).

\section{LITERATURE REVIEW}

Mathematical representation plays a role in improving the understanding of mathematical concepts and solving mathematical problems of students. In that way, the mathematical representation enables students in solving an abstract mathematical problems become real. Mathematical representation can be presented in visual (e.g., charts, tables, sketches/drawings, and diagrams) and non-visual representations (e.g., mathematical equations and models) (Minarni at al., 2016; Thompson \& Chappell, 2007). Numerous studies related to visual representations have been conducted to discuss various problem solving of the word problem (Epstein at al., 2010; Geeslin \& Shavelson, 1975; Güler \& Author, 2011; Stylianou \& Silver, 2009; Thompson \& Chappell, 2007; Webel at al., 2016), with additional studies on the use of technology in mathematical representation (Kendal \& Stacey, 2003; Ohlsson, 1998; Reilly at al., 1997) and on the elements used to generate relationships in mathematics learning (Moon 
at al., 2013). Moreover, mathematical representation research related to socioeconomics has been carried out (Boulton-Lewis \& Halford, 1992; Martínez-Sierra at al., 2015; Minibaeva at al., 2016; Moon at al., 2013).

According to Goldin (2002), mathematical representation is one way to express mathematical ideas, which, in turn, enables students to understand a mathematical concept and determine the solution to a mathematical problem. Other research has highlighted the association between high-order thinking and mathematical representation (Tajudin \& Chinnappan, 2016). Hence, the importance of improving students' abilities in mathematical representation that has emerged in the learning of mathematics is in line with previous research (National Research Council, 2001).

Finally, due to the abstract nature of mathematical concepts, mathematical representation has become necessary in order to make it easier for students to solve difficult mathematical problems. Although one study indicated that mathematical representation actually delays mathematical problem-solving and communication among students (Mckendree at al., 2002), the general opinion confirmed that the use of representation in mathematics learning was very important (Gulkilik \& Arikan, 2012).

\section{METHOD}

\section{Research Design}

This study employed a quasi-experimental approach with a 2 × 3 factorial design (see Table 1). This form of experimental design has a control group. However, it was not sufficiently controlled the outside variables that affected the implementation of the experiment (Sugiyono, 2013). More specifically, it utilized a non-equivalent control group design. Sampling was carried out by simple random sampling.

Table 1

The $2 \times 3$ Factorial Design

\begin{tabular}{lccc}
\hline Learning Strategy & \multicolumn{3}{c}{ Self-Efficacy } \\
\cline { 2 - 4 } & High $\left(\mathrm{B}_{1}\right)$ & Moderate $\left(\mathrm{B}_{2}\right)$ & Low $\left(\mathrm{B}_{3}\right)$ \\
\hline Expository $\left(\mathrm{A}_{1}\right)$ & $\mathrm{A}_{1} \mathrm{~B}_{1}$ & $\mathrm{~A}_{1} \mathrm{~B}_{2}$ & $\mathrm{~A}_{1} \mathrm{~B}_{3}$ \\
\hline Think-talk-write $\left(\mathrm{A}_{2}\right)$ & $\mathrm{A}_{2} \mathrm{~B}_{2}$ & $\mathrm{~A}_{2} \mathrm{~B}_{2}$ & $\mathrm{~A}_{2} \mathrm{~B}_{3}$ \\
\hline
\end{tabular}

Explanation:

$\mathrm{A}_{1}=$ Students who applied the expository strategy

$\mathrm{A}_{2}=$ Students who applied the think-talk-write strategy

$\mathrm{B}_{1}=$ Students with high self-efficacy

$\mathrm{B}_{2}=$ Students with moderate self-efficacy

$\mathrm{B}_{3}=$ Students with low self-efficacy

$\mathrm{A}_{1} \mathrm{~B}_{1}=$ Students with high self-efficacy who applied the expository strategy

$A_{2} B_{1}=$ Students with high self-efficacy who applied the think-talk-write strategy

$A_{1} B_{2}=$ Students with moderate self-efficacy who applied the expository strategy

$A_{2} B_{2}=$ Students with moderate self-efficacy who applied the think-talk-write strategy

$A_{1} B_{3}=$ Students with low self-efficacy who applied the expository strategy

$A_{2} B_{3}=$ Students with low self-efficacy who applied the think-talk-write strategy 
This study applied two learning strategies: 1) the expository strategy in the control group, and 2) the think-talk-write strategy in the experimental group. In each group, the participants were divided into three sub-groups (high, moderate, and low self-efficacy), thus totalling up to six groups of students.

\section{Participants}

This experimental research was conducted at Junior High School in Semarang, Indonesia. The participants comprised 288 students of the eighth grade studying geometry and spatial relations, of which 64 students were sub-divided into two classes: the experimental group (32 students) and the control group (32 students). In the experimental class, subgroups were formed, consisted of 3-5 students, while in the control group, no subgroup was formed. Both the experimental class and group applied the same instruments and tools for in their learning process. During the treatment, the students' activities of both groups were observed three times.

\section{Data Collection}

For the purpose of this study, students' self-efficacy and mathematical representation ability scores were required. The self-efficacy scores were determined by a 30-item selfefficacy scale that have been tested for validity and reliability, while a mathematical representation ability test was used to determine the scores for this ability. Statements were made in the form of positive and negative statements aimed to find variation of student answers. First, the self-efficacy scale, developed by Sherer and Maddux (1982) and modified by Lee and Cheng (2012), was used to measure the students' certainty regarding their ability to solve mathematical problems. The items in this scale included authentic experience, vicarious experience, social persuasion, and the generation of emotions. The sources could be developed as statements on the questionnaire. The boundaries of each category were based on ideal values/scores and deviation standards. In order to scale the responses, a likert-type scale ranging from strongly agree to strongly disagree was employed. Second, a trial mathematical representation ability test comprising five essay questions that have been tested for validation were presented to the experimental group and the control group. The results of the trial test were analyzed, after which the findings were applied to the final mathematical representation ability test for both the groups.

Finally, before testing the hypothesis, the research data were analyzed using the ShapiroWilk test and the variance homogeneity test. In addition, a two-way analysis of variance (ANOVA) and the Scheffe post-hoc test were applied to analyze the differences between the groups. All the hypothesis testing was performed using the SPSS software at a significance level of 0.05 .

\section{FINDINGS}

The differences in the mathematical representation abilities between the students exposed to the expository strategy (A1) and those exposed to the think-talk-write strategy (A2) are presented in Table 2. The results also reveal that there are differences in the mathematical representation abilities between the students with high self-efficacy 
(B1), moderate self-efficacy (B2), and low self-efficacy (B3). Regarding the interactions in learning, there is an interaction effect between the learning strategies (A) and selfefficacy (B).

Table 2

ANOVA $(2 \times 3)$

\begin{tabular}{llll}
\hline Source Variance & $\mathrm{F}_{\text {count }}$ & $\mathrm{F}_{\text {table }}(\alpha=0.05)$ & Decision Test \\
\hline $\mathrm{A}$ & 63.82 & 4.01 & $\mathrm{H}_{0 \mathrm{~A}}$ rejected \\
$\mathrm{B}$ & 24.56 & 3.16 & $\mathrm{H}_{0 \mathrm{~B}}$ rejected \\
\hline Interactions A and B & 3.86 & 3.16 & $\mathrm{H}_{0 \mathrm{AB}}$ rejected \\
\hline
\end{tabular}

Note: Significance level $\alpha=0.05$

The results of the ANOVA showed that $\mathrm{H}_{0 \mathrm{~A}}$ is rejected, indicating that there are differences in the mathematical representation abilities between the students who applied the expository strategy $\left(\mathrm{A}_{1}\right)$ and those who applied the talk-think-write strategy $\left(\mathrm{A}_{2}\right)$. In addition, the findings indicated that $\mathrm{H}_{0 \mathrm{~B}}$ is rejected, which indicates that there are differences in the mathematical representation abilities between the students with high self-efficacy $\left(B_{1}\right)$, moderate self-efficacy $\left(B_{2}\right)$, and low self-efficacy $\left(B_{3}\right)$. Another calculation confirmed that $\mathrm{H}_{0 \mathrm{AB}}$ is rejected, showing that there is an interaction effect between the learning strategies (A) and self-efficacy (B). Furthermore, the marginal means of the $2 \times 3$ factorial design are presented in Table 3 .

Table 3

Marginal Means of the Factorial Design $(2 \times 3)$

\begin{tabular}{|c|c|c|c|c|}
\hline \multirow[t]{2}{*}{ Learning Strategy } & \multicolumn{3}{|c|}{ Self-Efficacy } & Average \\
\hline & $\operatorname{High}\left(B_{l}\right)$ & Middle $\left(B_{2}\right)$ & $\operatorname{Low}\left(B_{3}\right)$ & Marginal \\
\hline Expository $\left(\mathrm{A}_{1}\right)$ & $74.29\left(\mathrm{~A}_{1} \mathrm{~B}_{1}\right)$ & $62.67\left(\mathrm{~A}_{1} \mathrm{~B}_{2}\right)$ & $53.00\left(\mathrm{~A}_{1} \mathrm{~B}_{3}\right)$ & $63.32\left(\mathrm{~A}_{1}\right)$ \\
\hline Think-talk-write $\left(\mathrm{A}_{2}\right)$ & $82.00\left(\mathrm{~A}_{2} \mathrm{~B}_{1}\right)$ & $75.92\left(\mathrm{~A}_{2} \mathrm{~B}_{2}\right)$ & $72.73\left(\mathrm{~A}_{2} \mathrm{~B}_{3}\right)$ & $76.88\left(\mathrm{~A}_{2}\right)$ \\
\hline Average marginal effect & $78.14\left(\mathrm{~B} .1_{1}\right)$ & $69.29\left(\mathrm{~B} .2_{2}\right)$ & $62.86\left(\mathrm{~B} .3_{3}\right)$ & \\
\hline
\end{tabular}

The implications of the results in Table 3 are presented in Tables 4 to 8 .

Table 4

Scheffe's Test regarding the Main Effect between the Learning Strategies

\begin{tabular}{llllll}
\hline Comparison & $\mathrm{H}_{0}$ & $\mathrm{H}_{1}$ & $\mathrm{~F}_{\text {count }}$ & $\mathrm{F}_{0,05 ; 1 ; 58}$ & Decision Test \\
\hline $\mathrm{A}_{1}$ vs $\mathrm{A}_{2}$ & $\mathrm{~A}_{1 .}=\mathrm{A}_{2}$ & $\mathrm{~A}_{1 .} \neq \mathrm{A}_{2}$ & 268.39 & 4.01 & $\mathrm{H}_{0}$ rejected \\
\hline
\end{tabular}

The findings of Scheffe's post-hoc test between $A_{1}$ and $A_{2}$ showed that $H_{0}$ is rejected, indicating that differences exist in the mathematical representation abilities between the students exposed to the expository strategy and those exposed to the think-talk-write strategy. Moreover, the results of the average group comparison showed that the average marginal effect for $A_{1}$ is greater than that for $A_{2}$ (see Table 4). This finding indicates that the effect of the mathematical representation ability test on the students in the experimental group is higher than that on the students in the control group. 
Table 5

Scheffe's Test regarding the Main Effect among Self-Efficacy

\begin{tabular}{lllll}
\hline Comparison & $\mathrm{H}_{0}$ & $\mathrm{~F}_{\text {count }}$ & $\mathrm{F}_{0.052258}$ & Decision Test \\
\hline $\mathrm{B}_{.1}$ vs B $_{.2}$ & $\mathrm{~B}_{.1}=\mathrm{B}_{.2}$ & 18.38 & $2(3.16)=6.32$ & $\mathrm{H}_{01}$ rejected \\
\hline $\mathrm{B}_{.1}$ vs B .3 & $\mathrm{~B}_{.1}=\mathrm{B}_{.3}$ & 50.04 & $2(3.16)=6.32$ & $\mathrm{H}_{02}$ rejected \\
\hline $\mathrm{B}_{.2}$ vs B $\mathrm{B}_{.3}$ & $\mathrm{~B}_{.2}=\mathrm{B}_{.3}$ & 10.93 & $2(3.16)=6.32$ & $\mathrm{H}_{03}$ rejected \\
\hline
\end{tabular}

As shown in Table 5, $\mathrm{H}_{01}$ is rejected, indicating that differences exist in the mathematical representation abilities between the students with high self-efficacy $\left(\mathrm{B}_{1}\right)$ and those with moderate self-efficacy $\left(\mathrm{B}_{._{2}}\right)$, and between the students with high selfefficacy (B. ) $_{\text {) }}$ and those with low self-efficacy (B.3). Furthermore, $\mathrm{H}_{03}$ is rejected, showing that there are differences in the mathematical representation abilities between the students with moderate self-efficacy and those with low self-efficacy. Furthermore, a comparison of the mean groups showed that the average marginal effect for B1 was greater than that for B2.

Table 6

Scheffe's Test regarding the Simple Effect among Self-Efficacy

\begin{tabular}{llcl}
\hline Comparison & $\mathrm{H}_{0}$ & $\mathrm{~F}_{0.05 ; 5 ; 58}$ & Decision Test \\
\hline $\mathrm{A}_{1} \mathrm{~B}_{1}$ vs. $\mathrm{A}_{2} \mathrm{~B}_{1}$ & $\mathrm{~A}_{1} \mathrm{~B}_{1}=\mathrm{A}_{2} \mathrm{~B}_{1}$ & 23.06 & $\mathrm{H}_{01}$ rejected \\
\hline $\mathrm{A}_{1} \mathrm{~B}_{2}$ vs. $\mathrm{A}_{2} \mathrm{~B}_{2}$ & $\mathrm{~A}_{1} \mathrm{~B}_{2}=\mathrm{A}_{2} \mathrm{~B}_{2}$ & 103.95 & $\mathrm{H}_{02}$ rejected \\
\hline $\mathrm{A}_{1} \mathrm{~B}_{3}$ vs. $\mathrm{A}_{2} \mathrm{~B}_{3}$ & $\mathrm{~A}_{1} \mathrm{~B}_{3}=\mathrm{A}_{2} \mathrm{~B}_{3}$ & 186.33 & $\mathrm{H}_{03}$ rejected \\
\hline
\end{tabular}

Table 6 shows that $\mathrm{H}_{01}$ is rejected, confirming that there are differences between the mathematical representation abilities of the students with high self-efficacy that applied the expository strategy $\left(A_{1} B_{1}\right)$ and those that employed the think-talk-write strategy $\left(A_{2}\right.$ $\mathrm{B}_{1}$ ). In addition, $\mathrm{H}_{02}$ is rejected, showing that there are differences in the mathematical representation abilities between the students with moderate self-efficacy that used the expository strategy $\left(A_{1} B_{2}\right)$ and those that applied the talk-think-write strategy $\left(A_{2} B_{2}\right)$.

Table 7 shows that there are differences between the mathematical representation abilities of the students with low self-efficacy that applied the expository strategy $\left(\mathrm{A}_{1}\right.$ $\left.B_{3}\right)$ and those that used the think-talk-write strategy $\left(A_{2} B_{3}\right)$. Moreover, a comparison of the groups confirms that $\left(\mathrm{A}_{1} \mathrm{~B}_{1}\right)=74.29<\left(\mathrm{A}_{2} \mathrm{~B}_{1}\right)=82.00$, indicating that the students with high self-efficacy who employed the think-talk-write strategy have an average proficiency score greater than that for the students who used the expository strategy. Furthermore, a second comparison confirms that $\left(\mathrm{A}_{1} \mathrm{~B}_{2}\right)=62.68<\left(\mathrm{A}_{2} \mathrm{~B}_{2}\right)=75.91$, showing that the students with moderate self-efficacy who used the think-talk-write strategy have an average proficiency score that is greater than that for the students who applied the expository strategy. The third comparison, $\left(\mathrm{A}_{1} \mathrm{~B}_{3}\right)=53.00<\left(\mathrm{A}_{2} \mathrm{~B}_{3}\right)=$ 72.73 , shows that the students with low self-efficacy who applied the think-talk-write strategy have an average proficiency score that is greater than that for the students who employed the expository strategy. 
Table 7

Scheffe's Test regarding the Interaction Effect between the Expository Strategy and Self-Efficacy

\begin{tabular}{ccccc}
\hline Comparison & $\mathrm{H}_{0}$ & $\mathrm{~F}_{\text {count }}$ & $\mathrm{F}_{0,05: 5: 58}$ & Decision Test \\
\hline $\mathrm{A}_{1} \mathrm{~B}_{1}$ vs. $\mathrm{A}_{1} \mathrm{~B}_{2}$ & $\mathrm{~A}_{1} \mathrm{~B}_{1}=\mathrm{A}_{1} \mathrm{~B}_{2}$ & 14.69 & $5(2.37)=11.85$ & $\mathrm{H}_{0}$ rejected \\
\hline $\mathrm{A}_{1} \mathrm{~B}_{1}$ vs. $\mathrm{A}_{1} \mathrm{~B}_{3}$ & $\mathrm{~A}_{1} \mathrm{~B}_{1}=\mathrm{A}_{1} \mathrm{~B}_{3}$ & 175.61 & $5(2.37)=11.85$ & $\mathrm{H}_{0}$ rejected \\
\hline $\mathrm{A}_{1} \mathrm{~B}_{2}$ vs. $\mathrm{A}_{1} \mathrm{~B}_{3}$ & $\mathrm{~A}_{1} \mathrm{~B}_{2}=\mathrm{A}_{1} \mathrm{~B}_{3}$ & 53.27 & $5(2.37)=11.85$ & $\mathrm{H}_{0}$ rejected \\
\hline
\end{tabular}

Table 7 also shows that $\mathrm{H}_{01}$ is rejected, indicating that there are differences in the mathematical representation abilities between the students with high self-efficacy who used the expository strategy $\left(A_{1} B_{1}\right)$ and those with moderate self-efficacy $\left(A_{1} B_{2}\right)$. The results also show that $\mathrm{H}_{02}$ is rejected, indicating that there are differences in the mathematical representation abilities between students with high self-efficacy $\left(A_{1} B_{1}\right)$ who applied the expository strategy and those with low self-efficacy $\left(\begin{array}{lll}A_{1} & B_{3}\end{array}\right)$. Furthermore, there are differences in the mathematical representation abilities between students with moderate self-efficacy $\left(\mathrm{A}_{1} \mathrm{~B}_{2}\right)$ who used the expository strategy and those with low self-efficacy $\left(\mathrm{A}_{1} \mathrm{~B}_{3}\right)$.

A comparison of the groups confirms that $\left(A_{1} B_{1}\right)=74.29>\left(A_{1} B_{2}\right)=62.67$, showing that students with high self-efficacy who applied the expository strategy have a higher average score on the mathematical representation ability test than those with moderate self-efficacy. Moreover, the findings show that $\left(\mathrm{A}_{1} \mathrm{~B}_{1}\right)=74.29>\left(\mathrm{A}_{1} \mathrm{~B}_{3}\right)=53.00$, indicating that students with high self-efficacy who employed the expository strategy have a higher average score on the mathematical representation ability test than those with low self-efficacy. Another comparison also shows that $\left(A_{1} B_{2}\right)=62.67>\left(A_{1} B_{3}\right)=$ 53.00 , illustrating that students with moderate self-efficacy who applied the expository strategy have a higher average score on the mathematical representation ability test than those with low self-efficacy.

Table 8

Scheffe's Test regarding the Interaction Effect between the Think-Talk-Write Strategy and Self-Efficacy

\begin{tabular}{llcll}
\hline Comparison & $\mathrm{H}_{0}$ & $\mathrm{~F}_{\text {count }}$ & $\mathrm{F}_{0.0555558}$ & Decision Test \\
\hline $\mathrm{A}_{2} \mathrm{~B}_{1}$ vs. $\mathrm{A}_{2} \mathrm{~B}_{2}$ & $\mathrm{~A}_{2} \mathrm{~B}_{1}=\mathrm{A}_{2} \mathrm{~B}_{2}$ & 17.76 & $5(2.37)=11.85$ & $\mathrm{H}_{0}$ rejected \\
\hline $\mathrm{A}_{2} \mathrm{~B}_{1}$ vs. $\mathrm{A}_{2} \mathrm{~B}_{3}$ & $\mathrm{~A}_{2} \mathrm{~B}_{1}=\mathrm{A}_{2} \mathrm{~B}_{3}$ & 41.17 & $5(2.37)=11.85$ & $\mathrm{H}_{0}$ rejected \\
\hline $\mathrm{A}_{2} \mathrm{~B}_{2}$ vs. $\mathrm{A}_{2} \mathrm{~B}_{3}$ & $\mathrm{~A}_{2} \mathrm{~B}_{2}=\mathrm{A}_{2} \mathrm{~B}_{3}$ & 5.08 & $5(2.37)=11.85$ & $\mathrm{H}_{0}$ rejected \\
\hline
\end{tabular}

Table 8 shows that there are differences in the mathematical representation abilities between students with high self-efficacy $\left(\mathrm{A}_{2} \mathrm{~B}_{1}\right)$ that applied the think-talk-write strategy and those with moderate self-efficacy $\left(\mathrm{A}_{2} \mathrm{~B}_{2}\right)$. In addition, there are differences in the mathematical representation abilities between students with high self-efficacy $\left(\mathrm{A}_{2} \mathrm{~B}_{1}\right)$ who used the think-talk-write strategy and those with low self-efficacy $\left(\mathrm{A}_{2} \mathrm{~B}_{3}\right)$. The table also shows that $\mathrm{H}_{03}$ is rejected, indicating that there are no differences in the mathematical representation abilities of students with moderate self-efficacy $\left(A_{2} B_{2}\right)$ who employed the think-talk-write strategy and those with low self-efficacy $\left(A_{2} B_{3}\right)$. Furthermore, a comparison of the groups shows that $\left(\mathrm{A}_{2} \mathrm{~B}_{1}\right)=82.00>\left(\mathrm{A}_{2} \mathrm{~B}_{2}\right)=75.919$, 
indicating that students with high self-efficacy who utilized the think-talk-write strategy have a higher average score on the mathematical representation ability test than those with moderate self-efficacy. The results also show that $A_{2} B_{1}$ is greater than $A_{2} B_{3}(82.00$ $>72.73$ ), meaning that students with high self-efficacy who used the think-talk-write strategy have a higher average score on the mathematical representation ability test than those with low self-efficacy.

Overall, the mathematical representation ability scores of the experimental group were better than those of the control group. This was confirmed by examining the answers to the following question in Figure 1 and Appendix:

Problem: "A pyramid has a base with a right triangle. The lengths of the two sides of the right triangle are $6 \mathrm{~cm}$ and $8 \mathrm{~cm}$, with a height of $12 \mathrm{~cm}$. Then, both the lengths of the two sides as well as the height of the pyramid were enlarged twice. Calculate the volume of the pyramid."

Figure 1 Mathematical Problem for Mathematical expressions ability

The student answers are evaluated according to Scoring Guideline as presented in Table 10 .

Table 10

The Scoring Guidelines for Mathematical Representation

\begin{tabular}{llll}
\hline Score & Written Texts & Visual Representation & Mathematical expressions \\
\hline 4 & $\begin{array}{l}\text { The explanation is } \\
\text { mathematically plausible, } \\
\text { clear and logically arranged. }\end{array}$ & $\begin{array}{l}\text { Describe diagram/ picture } \\
\text { completely, correct and } \\
\text { systematic. }\end{array}$ & $\begin{array}{l}\text { Find the mathematical } \\
\text { model correctly, then do the } \\
\text { calculation or obtain the } \\
\text { solution accurately and } \\
\text { systematically }\end{array}$ \\
\hline 3 & $\begin{array}{l}\text { The explanation is } \\
\text { mathematically plausible and } \\
\text { correct. However, it is not } \\
\text { logically arranged or there are } \\
\text { few language errors }\end{array}$ & $\begin{array}{l}\text { Describe diagrams/ } \\
\text { drawings, but the answers } \\
\text { are incomplete and } \\
\text { inaccurate }\end{array}$ & $\begin{array}{l}\text { Find the mathematical } \\
\text { model correctly, then obtain } \\
\text { the solution but } \\
\text { miscalculation }\end{array}$ \\
\hline 2 & $\begin{array}{l}\text { The mathematical is } \\
\text { mathematically } \\
\text { understandable and correct but } \\
\text { only partially complete }\end{array}$ & $\begin{array}{l}\text { Describe diagrams/ } \\
\text { drawings, but less }\end{array}$ & $\begin{array}{l}\text { Finding the mathematical } \\
\text { model correctly, but wrong } \\
\text { in obtaining the solution }\end{array}$ \\
\hline 1 & $\begin{array}{l}\text { Just a few of the correct } \\
\text { explanations }\end{array}$ & $\begin{array}{l}\text { Just a few of the } \\
\text { drawings/diagrams, but less } \\
\text { complete and inaccurate }\end{array}$ & $\begin{array}{l}\text { Just a few of the correct } \\
\text { mathematical models. }\end{array}$ \\
& $\begin{array}{l}\text { There is no answer, even though answer is found, it shows ignorance of concept and } \\
\text { hence the given information is not significance }\end{array}$ & \\
\hline 0
\end{tabular}

The sample of answer between the control group and the experimental group are shown in Figures 2 and 3. 


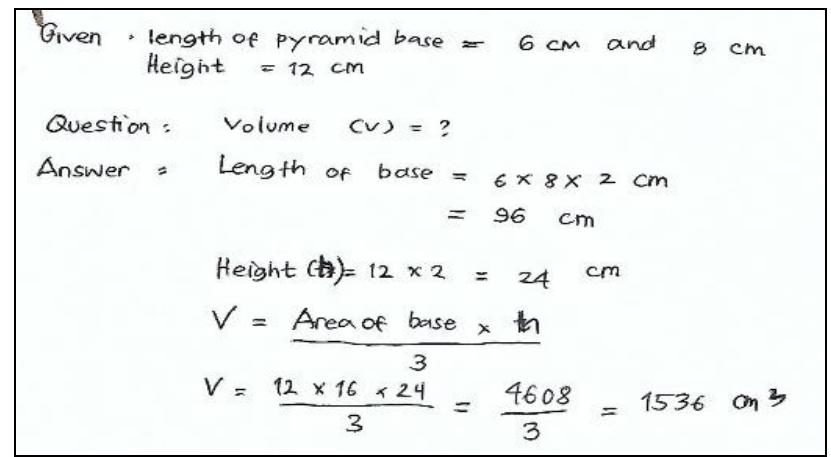

Figure 2 One Sample of Answer to the Mathematical Problem from the Control Group

Based on the scoring guidelines, the answer in Figure 2 received a score of 2, indicating that the student could correctly determine the mathematical model but was unable to obtain the correct solution.

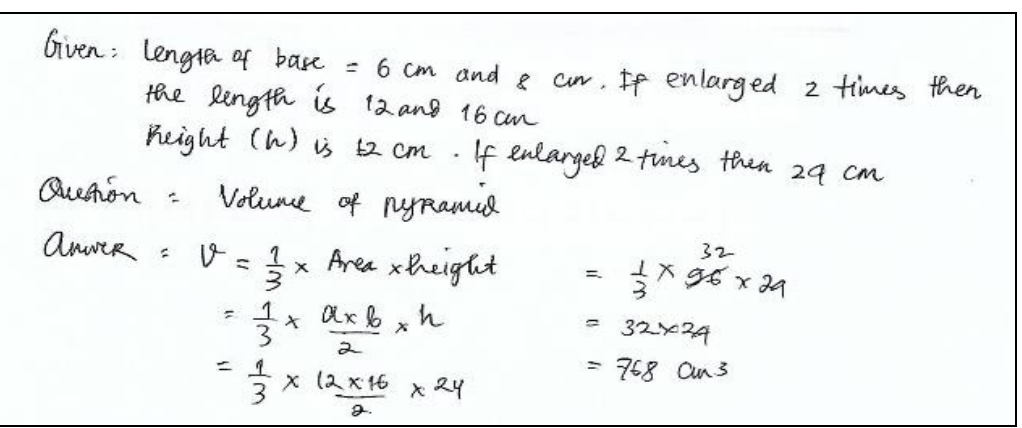

Figure 3 One Sample of Answer to the Mathematical Problem from the Experimental Group

Based on the scoring guidelines, the answer in Figure 3 received a score of 4 , which indicates that the student was able to correctly determine the mathematical model as well as obtain the correct solution. The sample of students' answers to the mathematical representation ability test question (written texts and visual representation) are presented consecutively in Figure 4 and Figure 5.

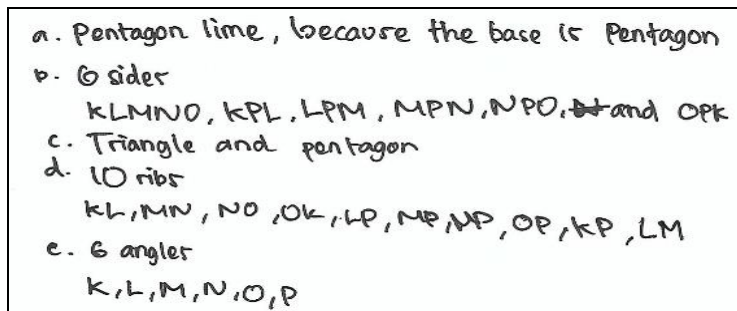

Figure 4. One Sample of Answer to the Mathematical Problem for written texts ability (score 4) 


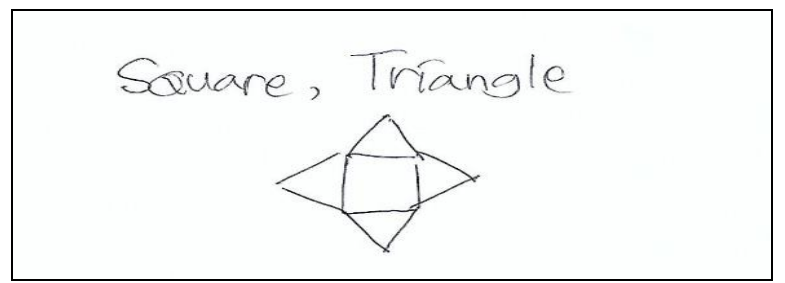

Figure 5. One Sample of Answer to the Mathematical Problem for visual representation ability (score 2)

The percentages of indicators regarding the achievement of the mathematical solving problem are shown in Table 11.

Table 11

Percentage Indicators Regarding the Achievement of the Mathematical Problems

\begin{tabular}{lll}
\hline Indicator & Experimental group & Control group \\
\hline Visual & $40.63 \%$ & $21.88 \%$ \\
\hline Mathematical expressions & $25.00 \%$ & $15.66 \%$ \\
\hline Written texts & $43.75 \%$ & $18.75 \%$ \\
\hline
\end{tabular}

According to Table 11, for visual representations, 13 students $(40.63 \%)$ in the experimental group correctly answered the mathematical problem, whereas only seven students $(21.88 \%)$ in the control group correctly answered the problem. For mathematical expressions, eight students $(25 \%)$ in the experimental group correctly answered the problem, compared to the five students $(15.63 \%)$ in the control group. Finally, for written texts, 14 students $(43.75 \%)$ in the experimental group correctly answered the problem, compared to the six students (18.75\%) in the control group.

\section{DISCUSSION AND CONCLUSION}

This study examined the effects of the think-talk-write strategy and the expository strategy on students' abilities in mathematical representation in order to understand the relationship between mathematical representation and self-efficacy. For the purpose of this study, two learning strategies were employed: 1) the expository strategy in the control group and 2) the think-talk-write strategy in the experimental group. In each group, the participants were sub-divided into three groups according to high, moderate, and low self-efficacy. Hence, a total of six groups of students were arranged. In addition, the mathematical representation ability and self-efficacy scale tests were used as instruments to measure the students' abilities in mathematical representation as well as their self-efficacy levels.

Through multiple methods, including the ANOVA and Scheffe's post-hoc method, differences in the mathematical representation abilities between students who used the expository strategy and those who applied the think-talk-write strategy were found. More specifically, the analyses indicated that students who employed the latter strategy had greater abilities in mathematical representation than those who used the former strategy. The results also indicated that there are differences in the mathematical representation abilities of students according to their self-efficacy levels, with the higher 
levels of self-efficacy indicating greater confidence in such abilities. Furthermore, there was the effect of learning strategies on the interaction of self-efficacy and mathematical representation.

Based on the authors' class observations during the learning process with the think-talkwrite strategy, many students were enthusiastic about learning mathematics, and actively presented questions and competitively addressed the problems and answers. Moreover, the students were eager to improve their mathematical representation abilities. Conversely, many students in the control group avoided the discussions and were embarrassed to answer any mathematical question. According to these observations, it is confirmed that the students in the experimental group had greater self-confidence in their mathematical representation abilities than those in the control group. The ability of mathematical representation in the experimental group is better than the control group for a visual presentation, mathematical expressions, or written text with a percentage of $36.46 \%$ (the control class is $18.76 \%$ ). Hence, the treatment of learning strategies can improve students in developing ideas of answers to solve mathematical problems.

Thus, students with high self-efficacy had a higher average score on the mathematical representation ability test than those with moderate or low self-efficacy. In addition, students with moderate self-efficacy had a higher average score on the mathematical representation ability test than those with low self-efficacy. More specifically, students with high self-efficacy had greater confidence in completing their tasks and clearly presenting their mathematical thinking processes, while students with moderate selfefficacy only performed the tasks set by the teacher. Meanwhile, students with low selfefficacy were easily frustrated and eventually gave up when the task became difficult. Thus, the findings show that the level of self-efficacy significantly affects students' mathematical representation abilities.

The implication of the findings is that the self-confidence levels of students can be applied in learning models in order to map their academic achievement. Therefore, it is important for scholars and academicians to continue focusing on different ways in order to improve the self-efficacy of students. Finally, although this study utilized two strategies (the think-talk-write strategy and the expository strategy) and examined their effects on a sample of junior high school students, future studies should not only investigate other approaches for increasing students' self-efficacy in mathematics but should also focus on a larger demographic in order to generalize the results of this study.

\section{REFERENCES}

Bandura, A. (1997). Self-Efficacy The Exercise of Control. New York: W. H Freeman and Company.

Boulton-Lewis, G., \& Halford, G. (1992). The Processing Loads of Young Children's and Teachers' Representation of Place Value and Implication for Teaching. Mathematics Education Research Journal, 4/1, 1-23. 
Chick, H., \& Watson, J. (2001). Data Representation and Interpretation by Primary School Students Working in Groups. Mathematics Education Research Journal, 13/2, 91-111.

Epstein, D., Mendick, H., \& Moreau, M. (2010). Imagining the mathematician : young people talking about popular representations of maths. Discourse: Studies in the Cultural Politics of Education, 31/1, 45-60. https://doi.org/10.1080/01596300903465419

Geeslin, W. E., \& Shavelson, R. J. (1975). An Exploratory Analysis of the Representation of a Mathematical Structure in Students' Cognitive Structures. American Educational Research Journal, 2/1, 21-39. https://doi.org/10.3102/00028312012001021

Goldin, G. (2002). Representation in Mathematical Learning and Problem Solving. In L. D. English, M. B. Bussi, G. A. Jones, R. A. Lesh, \& D. Tirosh (Eds.), Hand Book Of Internatıonal Research In Mathematıcs Educatıon (Pp. 197-218). London: Lawrence Erlbaum Associates.

Güler, G., \& Author, C. (2011). The visual representation usage levels of mathematics teachers and students in solving verbal problems. International Journal of Humanities and Social Science, 1/1, 145-154.

Gulkilik, H., \& Arikan, A. (2012). Preservice secondary mathematics teachers ' views about using multiple representations in mathematics instruction. Procedia - Social and Behavioral Sciences, 47, 1751-1756. https://doi.org/10.1016/j.sbspro.2012.06.895

Hoffman, B., \& Spatariu, A. (2008). The influence of self-efficacy and metacognitive prompting on math problem-solving efficiency. Contemporary Educational Psychology, 33, 875-893. https://doi.org/10.1016/j.cedpsych.2007.07.002

Kalathil, R. R., \& Sherin, M. G. (2000). Role of Students 'Representations in the Mathematics Classroom. In Fourth International Conference on the Learning Sciences (pp. 27-28).

Kendal, M., \& Stacey, K. (2003). Tracing Learning of Three Representations with the Differentiation Competency Framework. Mathematical Thinking and Learning, 15/1, $22-41$.

Lee, C. Y. \& Cheng, C. Y. (2012). The effects of worked examples on fifth graders' flexible thinking and mathematics attitudes. Proceedings of the 2012 International Conference on Mathematics and Information Education (ICMIE2012), pp. 61-72. Taipei, Taiwan. July 16-17, 2012.

Martínez-Sierra, G., Valle-zequeida, M. E., Miranda-tirado, M., \& Dolores-flores, C. (2015). Social Representations of High School Students About Mathematics Assessment Social Representations of High School Students About Mathematics. Canadian Journal of Science, Mathematics and Technology Education, Nov 2015, 1-13. https://doi.org/10.1080/14926156.2015.1119336 
Mckendree, J., Small, C., \& Stenning, K. (2002). The Role of Representation in Teaching and Learning Critical Thinking. Educational Review, 54/1, 57-67. https://doi.org/10.1080/00131910120110884

Minarni, A., Napitupulu, E. E., \& Husein, R. (2016). Mathematical Understanding And Representation Ability Of Public Junior High School In North Sumatra. Journal on Mathematics Education, 7/1, 43-56.

Minibaeva, S. V, Sh, L., Peregudina, T. N., Ivanova, E. I., \& Staritsyna, J. A. (2016). Artistic Representation of the State " fear" in the Written Text. IEJME-Mathematics Education, 11/5, 1297-1304.

Moon, K., Brenner, M. E., Jacob, B., \& Okamoto, Y. (2013). Prospective Secondary Mathematics Teachers ' Understanding and Cognitive Difficulties in Making Connections among Representations. Mathematical Thinking and Learning, 15, 201227. https://doi.org/10.1080/10986065.2013.794322

National Council of Teachers of Mathematis (2000). Principles and Standards for School Mathematics. United States of America: Reston, VA.

National Research Council. (2001). Adding it up: Helping children learn mathematics, J. Kilpatrick, J. Swafford, and B. Findell (Eds.). Mathematics Learning Study Committee, Center for Education, Division of Behavioral and Social Sciences and Education. Washington, DC: National Academy Press

Ohlsson, S. (1998). Representation and Process in Learning Environments for Mathematics : A Commentary on Three Systems. Interactive Learning Environments, 5, 205-215. https://doi.org/10.1080/1049482980050113

Reilly, D. O., Pratt, D., \& Winbourne, P. (1997). Constructive and instructive representation. Journal of Information Technology for Teacher Education, 6/1, 73-93. https://doi.org/10.1080/14759399700200001

Rutherford, T., Long, J. J., \& Farkas, G. (2017). Teacher value for professional development, self-efficacy, and student outcomes within a digital mathematics intervention. Contemporary Educational Psychology, 51, 22-36. https://doi.org/10.1016/j.cedpsych.2017.05.005

Sherer, M. \& Maddux J. (1982). The self-efficacy scale: Construction and validation, Psychological Reports, 51(2), 663-671.

Siriparp, T. (2015). Examining Self-efficacy and Achievement in an Educational Research Course. Procedia - Social and Behavioral Sciences, 171, 1360-1364. https://doi.org/10.1016/j.sbspro.2015.01.254

Skaalvik, E. M., Federici, R. A., \& Klassen, R. M. (2015). Mathematics achievement and self-efficacy: Relations with motivation for mathematics. International Journal of Educational Research, 72, 129-136. https://doi.org/10.1016/j.ijer.2015.06.008 
Stylianou, D. A., \& Silver, E. A. (2009). The Role of Visual Representations in Advanced Mathematical Problem Solving: An Examination of Expert- Novice Similarities and Differences. Mathematical Thinking and Learning, 6/4, 353-387.

Sugiyono. (2013). Quantitative Research Methods, Qualitative and R\&D, pp. 114, Bandung: Alfabeta.CV ( In Indonesian)

Tajudin, N. M., \& Chinnappan, M. (2016). The Link between Higher Order Thinking Skills, Representation and Concepts in Enhancing TIMSS Tasks. International Journal of Instruction, 9/2, 199-214. https://doi.org/10.12973/iji.2016.9214a

Thompson, D. R., \& Chappell, M. F. (2007). Communication and Representation as Elements in Mathematical Literacy. Reading \& Writing Quarterly: Overcoming Learning Difficulties, 23, 179-196. https://doi.org/10.1080/10573560601158495

Webel, C., Krupa, E., \& McManus, J. (2016). Using Representations of Fraction Multiplication. Teaching Children Mathematics, 22/6, 366-373.

Xu, Z., \& Jang, E. E. (2017). The role of math self-efficacy in the structural model of extracurricular technology-related activities and junior elementary school students mathematics ability. Computers in Human Behavior, 68, 547-555. https://doi.org/10.1016/j.chb.2016.11.063

\section{Appendix}

1. Mathematical problem of visual representation

Students take one of the gift boxes as illustrated in the picture and have it cut.

a. What is the shape of the cutting?

$b$. Sketch the answer of $(a)$

\section{Mathematical problem of Written Texts}

Observe the following Figure.

a. What is the name of the $3 D$ geometric shape of the image? Give your reason!

b. How many sides does the shape have? Mention!

c. What is the type of sides that formed the image? Mention!

d. How many edges does the image have? Mention! e. How many vertexes does the image have? Mention
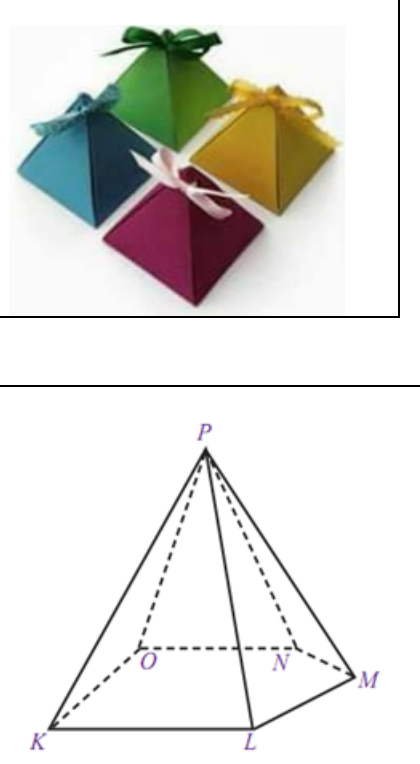